\title{
POLYCENTRIC APPROACH TO GLOBAL CONSTITUTIONALISM AND CLIMATE CHANGE
}

\section{APROXIMACIÓN MULTIDIMENSIONAL AL CONSTITUCIONALISMO GLOBAL Y AL CAMBIO CLIMÁTICO}

\author{
ERNANI CONTIPELLI \\ Professor of Climate Law and Governance \\ Regional Community University of Chapecó (UNOCHAPECO, Brazil) \\ ernanicontipelli@gmail.com
}

Reception: 31 January 2019 / Acceptation: 7 March 2019

\begin{abstract}
The construction of the global constitutionalism's narrative requires interpretative efforts in order to recognize, at the same time, the basic values of the constitutionalism and the irreversible fragmentation of the international order, establishing legal frameworks to stimulate collective and coordinate actions in different scales of governance specially to handle top global threats as the case of the climate change. The polycentricity and its alternative and pluralistic approach that aims to maximize the potential convergence of multiple governance units appears in this context as an appropriate analytical method to develop a discursively narrative which generates a constitutional framework adjusted to handle with climate change, building the idea of a micro-globalclimate-constitutionalized system. Therefore, the micro-global-climateconstitutionalism bounded by a set of overarching rules as the United Nations Framework Convention on Climate Change (UNFCCC) and the constitutive and regulatory documents elaborated at the decision-making process of the Conference of Parties (COPs), specially the Kyoto Protocol and the Paris Agreement, supports the international climate regime, generating a scheme of comprehensive values and principles through uniform standards that oriented coordinated initiatives of higher and lower levels of authority towards a dynamic and progressive model of governing.
\end{abstract}


RESUMEN: La construcción de la narrativa del constitucionalismo global requiere esfuerzos interpretativos para reconocer, al mismo tiempo, los valores básicos del constitucionalismo y la fragmentación irreversible del orden internacional, estableciendo marcos legales para estimular acciones colectivas y coordinadas a diferentes escalas de gobernanza especialmente para abordar las principales amenazas mundiales como el caso del cambio climático. La policentricidad y su enfoque alternativo y pluralista, que pretende maximizar la convergencia potencial de múltiples unidades de gobernanza, aparece en este contexto como un método analítico apropiado para desarrollar una narrativa discursiva que genere un marco constitucional ajustado al cambio climático, construyendo la idea de un sistema constitucionalizado climático micro global. Por lo tanto, el constitucionalismo climático micro global delimitado por un conjunto de reglas generales como la Convención Marco de las Naciones Unidas sobre el Cambio Climático (CMNUCC) y los documentos constitutivos y regulatorios elaborados en el proceso de toma de decisiones de la Conferencia de las Partes (COP), especialmente el Protocolo de Kyoto y el Acuerdo de París, respaldan el régimen internacional del clima, generando un esquema de valores y principios integrales a través de estándares uniformes que orienten iniciativas coordinadas de niveles de autoridad más altos y más bajos hacia un modelo de gobierno dinámico y progresivo.

RESUM: La construcció de la narrativa del constitucionalisme global requereix esforços interpretatius per tal de reconèixer, alhora, els valors bàsics del constitucionalisme i la fragmentació irreversible de l'ordre internacional, establint marcs legals per estimular accions collectives i coordinades a diferents escales de governança especialment per abordar les principals amenaces mundials com és el cas del canvi climàtic. La policentricitat i el seu enfocament alternatiu i pluralista, que pretén maximitzar la convergència potencial de múltiples unitats de governança, apareix en aquest context com un mètode analític adequat per desenvolupar una narrativa discursiva que generi un marc constitucional ajustat al canvi climàtic, construint la idea d'un sistema constitucionalitzat climàtic micro global. Per tant, el constitucionalisme climàtic micro global delimitat per un conjunt de regles generals com la Convenció Marc 
de les Nacions Unides sobre el Canvi Climàtic (CMNUCC) i els documents constitutius i normatius elaborats en el procés de presa de decisions de la Conferència de les Parts (COP), especialment el Protocol de Kyoto i l'Acord de París, donen suport al règim climàtic internacional, generant un esquema de valors i principis integrals a través de normes uniformes que orienten iniciatives coordinades de nivells d'autoritat superior i inferior cap a un model dinàmic $i$ progressiu de govern.

KEYWORDS: Polycentricity - Globalization - Fragmentation - Global Constitutionalism - Climate Change.

PALABRAS CLAVE: Policentrismo - Globalización - Fragmentación Constitucionalismo global - Cambio climático.

PARAULES CLAU: Policentricitat - Globalització - Fragmentació Constitucionalisme global - Canvi climàtic.

SUMMARY: I. Introduction. II. Global Constitutionalism. 1. Globalization and Nation-States. 2. Concept of Global Constitutionalism. II. Polycentric Approach and Climate Change. 1. Fragmentation: Polycentric Approach to Coping with Climate Change. III. Global Climate Constitutionalism? IV. Conclusion. V. References.

\section{INTRODUCTION}

The polycentric method pursues an alternative and pluralistic approach that balances the potential costs and benefits of having multiple, often overlapping domains of governance, to investigate social changes. In what concerns the question of global problems such as the climate crisis, which involves collective actions and transcends boundaries, polycentricity has to develop an approach to effectively reach the essence of the issues of common concern, which must be faced by the entire humanity, with cooperative efforts.

The global constitutionalism's narrative, in this context, appears as a mechanism to establish a set of comprehensive and overarching values, principles, and rules, which aim to insure the necessary coordination among polycentric pledges that have been developing in distinct scales of governance, with the participation of different actors and stakeholders, to cope with climate change. 
With the aim to analyse the relation between global constitutionalism and climate change within a polycentric approach, the first section of the present article will be dedicated to the study of the effects of globalization and the "dictatorship of international financial markets," through a transnational convergence of policies oriented to the process of capital accumulation in the current disrupted and distraught role of the Nation-States in the irreversible and fragmented international order.

Sequentially, the concept of global constitutionalism will be studied as an academic and politic agenda, which means, a discursive narrative that aims to enhance and maximize the potential of the fragmented international order. This will help to readjust the capacity of the Nation-State to suitably deal with collective goods and global problems and preserve the commonly accepted values and principles constructed through the length of history. This can be done by constitutionalism, generating micro-legal frameworks (or systems) that reach beyond the boundaries and capture the complexity and diversity of the society, integrating distinct scales of governance through a scheme of comprehensive rules established by constitutive and regulatory international documents related to a given issue, such as, the climate change.

On the basis of Elinor Ostrom's theory, the construction of the micro-globalconstitutionalized systems, through the polycentric approach, interrelates multiple levels of governance within the collective actions bounded by overarching rules, to achieve common goals. This method seems to be an appropriate tool to develop normative and descriptive elements of governance, to cope with the climate crisis.

Therefore, the micro-global climate constitutionalism recognizes the United Nations Framework Convention on Climate Change (UNFCCC) and the documents elaborated by the decision-making process of the Conference of Parties, especially the Kyoto Protocol and the Paris Agreement, as part of the foundational elements and dynamics of its system, establishing a legal framework for the international climate regime that aspires to be the guided essence of rules and procedures, as well as a multiplier of the actions of distinct actors and stakeholders, to overcome the climate crisis. 


\section{GLOBAL CONSTITUTIONALISM}

Comprehending the concept of Global Constitutionalism means analysing how it is embedded in international history, and at the same time, discursively constructing it, creating a narrative that promotes links between the past, present, and future of the respective society in certain periods of time ${ }^{1}$.

Influenced by the driving forces that act in the building-process of the Nationstate's profile, the dynamics of the Constitutional Structures comprise the integration of various empirical factors of power presented in "memory" of the world society, allocating values and determining the behavioural patterns of communities and citizens in particular moments of history.

As a product of experimental transformations, constitutionalism is connected to several elements (economic, political, sociological, anthropological, etc.) that affect the sources of the juridical phenomenon and its beliefs, values, and principles, to construct different interpretative approaches that aim to advocate a balance of multiple interactions between the State and Society.

This method of analysis allows the understanding of social implications and the impulses that generate the (re-) interpretation of constitutional structures in successive moments, as it applies perspectives from sociology and history to provide a better view of the mechanisms, which provide stability between the reality that is driven by social forces and its delivery schemes. The crucial abstract definitions, such as, the concept of global constitutionalism is more of an academic artefact than an actual constitution?2.

In this sequence of ideas, it is possible to argue that the current discussion about global constitutionalism is, in its essence, a "matter of globalization" as norms with constitutional repercussions are being produced in distinct scales of governance, inside, and particularly, outside of the Nation-states' frontiers. It means, the constitutional structures must renew their core concepts - by observing the results of the past and producing legal frameworks adjusted for

\footnotetext{
${ }^{1}$ MÜLLER, Thomas (2014). Global Constitutionalism in Historical Perspective: Towards refined tools for International Constitutional Histories, p. 87. Global Constitutionalism, 3: 1, pp. 71-101. Cambridge University Press.

2 MÜLLER, supra note 01 , at 86 .
} 
the future - as a path to develop strategies to compensate for on-going deconstitutionalization at the domestic level ${ }^{3}$.

\section{Globalization and Nation-States}

The twenty-first century's globalized world presents complex social factors that have developed a new set of controversial issues that affect all sectors of collective life, such as, the environmental and climate crisis. the rise of new technologies of information and communication, and the boom of internet that reduces distances across the planet; the delocalization of the capital and the increasing inequalities that put the existing social protection systems at risk; and the current economic and political crises, which impact the citizens' trustworthiness in the international and domestic orders.

Therefore, the role of the Nation-states in the new global political scenario has emerged as a series of debates, motivated by the evident decrease in its power and consequent anachronism of its institutional and regulatory functions. Most of the arguments that justified this point of view are founded by the intensified growth of transnational economic transactions that are being developed across national boundaries ${ }^{4}$, opening new fields of negotiating and turning the world progressively multipolar.

According to Dani Rodrik, the globalization's process that took place specially from the 1990s has replaced the excessive optimism about what the state would be able to accomplish, by the excessive pessimism, suggesting that the society is "on the threshold of a serious reconsideration of the role of the state in development, one that will lead to an improved understanding of the role that governments can (and have to) play, without the wide-eyed idealism of the $1960 s^{\prime \prime}$.

\footnotetext{
3 PETERS, A. (2006) Compensatory Constitutionalism: The Function and Potential of Fundamental International Norms and Structures. Leiden Journal of International Law, 19, 579610.

${ }^{4}$ EVANS, Peter (1997). The Eclipse of the State? Reflections on Stateness in an Era of Globalization, p. 63. World Politics, vol. 50, n. 01, pp. 62-87.

${ }^{5}$ RODRIK, Dani (1997). The 'Paradoxes' of the Successful State. European Economic Review, vol. 41 , issue $3-5,411-442$.
} 
Nowadays, it is necessary to rethink the Nation-state's role, to readjust its capacity to deal with collective goods, social protection, and the increasing power of transnational private corporations, proposing distinct forms and strategies of actions, guided by commonly accepted values and principles, oriented to the promotion of the general welfare in order to recover their image of effective actors at the global and domestic levels.

Of course, globalization is not the only cause for weakening of the state's authority, but it is the central one that runs through two interconnected channels: the development of transnational economic relations and its political effects that delimit the more restricting perspectives for state action ${ }^{6}$ and crafting, what is known as "the dictatorship of international financial markets" 7 .

One of the most prominent theories about the relationship between states and transnational economic relations is the "race-to-the-bottom," which accepts that capital mobility seeks a location of the lower regulatory standards, where it can earn the highest rate of return. In this scenario, high rates of corporate taxation, strict labor laws, or rigorous environmental protection, lowers the rates by raising the cost of production. This exposes the Nation-states to the dictatorship of international financial markets to avoid capital flight, consequently causing damage to their tax bases. Hence, globalization conduces a race to the bottom, which requires policies of a laissez-faire country, in which the environment, the treatment of labour, and the health of the consumers are sacrificed at the altar of commerce ${ }^{8}$.

The Nation-states that go in the opposite direction of the race-to-the-bottom's flow, implementing policies considered imprudent by the private financial traders' interests and offering them significant lower returns, would be economically and politically penalized, such as the case of their exchange rate that is rapidly depreciated and their capital which is outflowed.

Thereby, the capital mobility promoted by globalization requires a convergence of policies that will guarantee that owners of financial resources receive roughly the same, risk-adjusted, real return everywhere, intervening in the sphere of

\footnotetext{
${ }^{6}$ EVANS, supra note 04 , at 83.

7 BLOCK, Fred (1996). The Vampire States and Other Stories. New York: New Press.

8 DREZNER, Daniel W. (2001) Globalization and Policy Convergence, p. 57/59. International Studies Review, vol. 3, n. 1, pp. 53-78.
} 
sovereignty of the Nation-states ${ }^{9}$, as they impose on the establishment of uniform global standards to protect their economic interests and maximize their profits.

Karl Polanyi accurately predicted that the normative effects of the "race-to-thebottom", arguing that one society regulated by the market would work as an assistant of this market. Furthermore, he concluded: "To allow the market mechanism to be sole director of the fate of the human beings (...) would result in the demolition of society (...) Nature would be reduced to its elements, neighbourhoods and landscapes defiled, rivers polluted, military safety jeopardized, the power to produce food and raw material destroyed"10.

Throughout history, the capitalist international order always delivered certain schemes to advocate for the convergence of political and economic structures, to remove impediments to the process of capital accumulation. It always assigned a role to the Nation-states, according to the interests of the powerful international corporations. With globalization, the proposed homogenization process is reinforced toward the convergence of policies orientated by the acceleration of capital mobility and an accumulation that requires uniform global standards ${ }^{11}$, bringing to the fore a significant question: What model of convergence of politics is the world society looking for?

As a consequence, the rise of a system of policies and norms prescribed by the uniform global standards, which are produced outside of the border of Nationstates, reinforces the power of transnational corporations. Moreover, nowadays, that is the convergence that emperies in the current international order, as exposed by the race-to-the-bottom's theory, which forces the requirement of a strong movement in different sectors of the society that goes in the opposite direction, recovering the original essence of the public sphere and adapting it to the new complexities of the globalized world.

One of the main tasks related to the progressive convergence of policies that affects the decision-making process on different scales of governance is to

${ }^{9}$ CABLE, Vicent. (1995) The Diminished Nation-State: A Study in the Loss of Economic Power, p. 28. Daedalus, vol. 124, n. 02, What Future for the State?, pp. 23-53.

${ }_{10}$ POLANYI, Karl (1944). The Great Transformation, p. 57. Boston: Beacon Press.

${ }^{11}$ CHIMNI, B. S. (2004). International Institutions Today: An Imperial Global State in the Making, p. 07. European Journal of International Law, 15, pp. 01-37. 
equalize political practices, establishing a potential set of comprehensive values and principles, to develop its own legitimacy, and to accomplish consensusbuilding in the heterogeneous and instable relationship between institutions and citizens characterized by the presence of distinct actors and centres of dialog that act in overlapping jurisdictions. These considerations evidence the need for a cooperative approach among the Nation-states, international organizations, and non-state actors, especially through bilateral and multilateral negotiations and agreements ${ }^{12}$.

In this order of ideas, it is relevant to elaborate on a discursive narrative that claims for a program of values, principles, and rules, recognizing the gradual process of interdependence between international and domestic systems in order to recover the ideas of the constitutional heritage and conform to a global social agenda ${ }^{13}$ through interpretative efforts that generate a legal framework, which is able to recover and sustain the capacity of the Nation-States to deal with collective goods and their current planetary dimension ${ }^{14}$.

\section{Concept of Global Constitutionalism.}

The transformation of the institutional arrangements caused by globalization requires new approaches of governance, focused on the recognition of complex

\footnotetext{
12 PETERS, A. (2009) The Merits of Global Constitutionalism, p. 405. Indiana Journal of Global Studies: Vol. 16: Issue 2, Article 2, p. 397-411.

${ }^{13}$ Along history, the idea of constitutionalism can be comprehended in different ways, but it will always accomplish some core functions: Organize the power and create institutions and procedures, bounded by a set of commonly accepted values and principles that have to adapt themselves to certain social conditions over time, in order to sustain the basis of the juridical phenomenon. With the rise of 'alternative globalization', it emerges as a new mindset for the global constitutionalism marked by the idea of a 'more social law', especially, after the launch of the Agenda 2030, adopted by the UN General Assembly in 2015. Therefore, the social principle is revealed as part of the constitutional heritage of the international community, for example, the case of the UN Millennium Declaration that had been proposed by some analysts to be incorporated in national constitutions, 'constitutionalizing the MDGs (Millennium Development Goals)'. (PETERS, Anne, 2017, Global Constitutionalism: The Social Dimension, p. 37. MPIL Research Paper Series, n. 2017-25).

${ }^{14}$ The globalization interferes in the dynamics of the collective goods as it evidences the existence of common problems in a planetary scale, generating the increasing of interdependence between nations and the need of a new political agenda in order to address efforts in the solution of global problems, also called as "problems without passport", as well defined by Kofi Annan, former Secretary General of UN. It means, the global problems can only be treaty by overpassing frontiers, problems that don't belong to this nation or that nation, but the whole world, collapsing the traditional idea of sovereignty as the comprehensive regulatory framework is no longer in the constitutional's frontiers and, consequentially, demanding cooperative efforts in order to find their solutions.
} 
interactions among distinct actors and the process of convergence of policies driven by the dictatorship of international financial markets that decisively influence the power's relation to the contemporary international order.

This scenario poses a real challenge to the constitutionalism, which needs to reach beyond the boundaries of the Nation-states to properly frame the complexity of the collective goods and promote welfare. This can be accomplished by avoiding the logic of exclusion of the current "convergence of policies" and by establishing uniform global standards that achieve reciprocity, solidarity, and mutual trust between institutions and citizens, and understanding the existence of different historical and cultural trajectories in an interdependent and fragmented world.

Thus, the Constitutional Structures must escape from the traditional concept of the "state centred" which was appropriate at the time of the "dualistic Westphalian system," and recognize the need to construct a discursive narrative that is able to offer a useful analytical tool in a world where the boundaries between domestic and international law have been progressively blurred, and where new polities have emerged that challenge the state's legal and political authority ${ }^{15}$.

The response for the "denationalization" of legal and political functions demands a balance that breaks "the statist frame" and escapes from the "all or nothing" propositions, as a necessary step to preserve the values of constitutionalism in an era of globalization and interdependence, finding, beyond the boundaries of the Nation-states, a pathway for an emerging constitutionalism that involves different levels of governance ${ }^{16}$.

On the one hand, this process of increasing "outsourcing of constitutional functions" implies a changing nature of the Constitutional Structures today and in the future, as they can no longer provide a comprehensive regulatory framework of the state on their own. Compared to its traditional perspectives, the Constitutional Structures are now considered as "partial constitution", being complemented by other levels of governance. On the other hand, it

15 COTTIER, Thomas and HERTIG, Maya (2003). The Prospects of $21^{\text {st }}$ Century Constitutionalism, p. 297. Max Planck Yearbook of United Nations Law, Volume 7, pp. 261-328. ${ }^{16}$ COTTIER and HERTIG, supra note 15 , at 297/298. 
demonstrates a rupture in the concept of absolute sovereignty, and subsequently, a rise in the system of competences, based on the sharing between different levels of governance ${ }^{17}$.

Certainly, the multi-layered patterns of governance are taking place outside of the states' confines as the race-to-the-bottom's theory has demonstrated, decreasing their power and discharging the Constitutional Structures, as their principles have become dysfunctional or empty ${ }^{18}$. Finally, the consequence of this process evidences the present goal of the Constitutional Structures: To survive in the fragmented international arena dominated by the "dictatorship of international markets".

Moreover, the idea of global constitutionalism appears as a mindful and comprehensive revision and reading of the degenerated contemporary concept of constitutionalism ${ }^{19}$, which aims to establish a compensation for the transference of the state's functions from the national to the international level and to adapt the core values offered by the constitutionalism's history to the current global social agenda

According to Anne Peters and Klaus Armigeon, the concept of global constitutionalism plays an important role in this context as "an academic and political agenda, which identifies and advocates the application of constitutionalist principles in the international legal sphere, in order to improve the effectiveness and the fairness of the international legal' 20 , stimulating the launch of descriptive and prescriptive elements into the global governance system, to pursue multiple arguments that object to the orientation of the development of institutional relations in a specific and convergent direction toward the promotion of public collective goods.

As a compensatory constitutionalism that juxtaposes the supranational with the national level, global constitutionalism supports the existence of the Nation-

\footnotetext{
17 COTTIER and HERTIG, supra note 15, at 304.

18 PETERS, A. (2007) The Constitutionalization of State Constitutions. In J. Nijman and A. Nollkaemper (Eds.) New Perspectives on the Divide Between National and International Law. Oxford: Oxford University Press, pp. 251-308.

${ }^{19}$ MÜLLER, supra note 01 , at 87.

20 PETERS, A. and ARMIGEON, K. (2009) Global Constitutionalism from an Interdisciplinary Perspective, p. 389. Indiana Journal of Global Legal Studies, vol. 16, n. 02, Special Issue, pp. 385-395.
} 
states, generating a "legal compensatory jurisdiction" accomplished by the international institutions that must be compatible with domestic politics and regulate the life of citizens ${ }^{21}$, bringing one main issue to the fore: How to meet certain uniform global standards that equalize legitimacy and constitutional principles?

Therefore, the problem is to transplant to the international level a specific conception of a Constitution that does not just consist of its simple relocation, but that encompasses a legal framework of substantive values and principles in line with the peculiarities of the international history and its driven forces, to effectively adjust to the decision-making process in the multi-layered global governance system.

Here, it is relevant to establish a distinction between: (a) Constitution in a normative perspective, which refers to an essential body of rules oriented to the governing of the social and political life of a community and is usually associated with a written form ${ }^{22}$; (b) Constitutionalization that involves a process extended through time that can attribute constitutional properties to a legal text (or various legal texts) ${ }^{23}$; and (c) Constitutionalism that comprises a scheme of fundamental values and principles that reflect the substantive conception of a constitution, such as the separation of powers, checks and balances, human rights, democracy, and currently, social issues like the environment, consumption, human development, and other significant affairs.

As a conclusion, there is a significant distinction between constitution and constitutionalism that makes possible the existence of a constitution without constitutionalism (as was true in former communist countries and in some developing countries) or even constitutionalism without a constitution ${ }^{24}$.

\footnotetext{
${ }^{21}$ ARMINGEON, K. and MILEWICZ, K. (2006) Compensatory Constitutionalism: A Comparative Perspective, p. 03. NCCR International Trade. Working Paper n. 13.

22 PETERS, supra note 03, at 581.

${ }^{23}$ PETERS, supra note 21 , at 582 .

${ }^{24}$ BODANSKY, Daniel (2009). Is There an International Environmental Constitution?, p. 569. Indiana Journal of Global Legal Studies, vol. 16, pp. 565-584.
} 
Based on this idea, it is also true that global constitutionalism does not require a global constitutional law ${ }^{25}$, allowing the recognition of the fragmentation as a pathway to harmonize the global governance system. Indeed, constitutionalism goes beyond the idea of a constitution and any institutional project, consisting of a program of moral and political regeneration that underlines certain values and principles, representing what Martti Koskenniemi mean by "constitutional mindsef'26.

In the globalized world, global constitutionalism is comprehended as a constant 'work-in-progress' that needs to structure its own narrative, linking procedures and substantive elements of constitutionalism and building a parallel social agenda toward the achievement of real collective goods in a multi-layered governance system, dictated by transnational economic transactions.

Instead it fosters static arrangements among Nation-states and other international actors, the global constitutionalism has to embrace the dynamism of the fragmented order ${ }^{27}$ imposed by globalization as an irreversible process and enhance its potential to preserve the values of constitutionalism.

By accepting and recognizing this situation, global constitutionalism could engage multiple stakeholders and levels of governance in a cooperative decision-making process that effectively addresses the convergence of policies toward the promotion of collective goods.

Working with the lowest level of international constitutionalism, Daniel Bondasky highlighted the constitutive aspects of many international agreements, especially those related to environmental affairs, which have a constitutional

25 GARDBAUM, Stephen (2009). Human Rights and International Constitutionalism, p. 30, in Ruling the World? Constitutionalism, International Law and Global Government, Jeffrey L. Dunoff, Joel P. Trachtman, Cambridge University Press, 2009.

${ }^{26}$ KOSKENNIEMI, Martti (2007). Constitutionalism as Mindset: Reflections on Katian Themes about International Law and Globalization, p. 18. Theoretical Inquires in Law 8.1, pp. 09-36.

27 VAN AAKEN, Anne (2009). Defragmentation of Public International Law Through Interpretation: A Methodological Proposal, p. 512. Indiana Journal of Global Legal Studies, vol. 16, pp. 483-512. According to her, the institutional and normative fragmentation of international law will presumably "stay with us for a quite while" which configures the opposite logic of this system as it strives for substantive unity and coherence. Thereby, it is necessary a mitigation of the fragmentation problem by the Nation-states, which could be reach through the interpretation process of the object and purposes of the international treaties that contributes to the harmonization of the whole system. 
dimension in a thin sense ${ }^{28}$, presenting flexibility and dynamism that establish the on-going systems of governance in order to address particular issues such as climate change, ozone depletion, and whaling. Following this idea, he sustained that "each environmental agreement performs basic constitutive functions by establishing institutions, specifying the rules that guide and constrain these institutions, and stretching these rules through amendment procedures" 29 .

Of course, the construction of micro-global-constitutionalized systems within the international framework requests a process of adjustment that involves the constitutive elements of a specific regime of principles and norms, its multiscale governance features and respective decision-making processes, as well as, how this particular system would respect the substantive idea of constitutionalism, escaping from the emptiness of "thicker perspectives".

Thomas Cottier and Maya Hertig explained that the constitution, as a normative concept, "has to meet certain requirements, its basic and core functions". Hence, "the maximalist concept of 'constitution' is moreover fraught with the risk that the Nation-state remains the only standard against which order governance structures are measured, which necessarily makes them seem underdeveloped and deficient' ${ }^{30}$. In this sense, it is significant to balance the idea of a thicker and a maximalist concept of constitution through a polycentric approach, which seeks to penetrate the reality of the fragmented and globalized international order, to enhance the coordinated existing linkages and overlapping jurisdictions among multiple governance units, not only in the Nation-States, but also to motivate collective actions and orientate them toward the achievement of common goals bounded by constitutionalist values and principles, and simultaneously, legitimated and dynamics procedures.

\footnotetext{
${ }^{28}$ Advocating for a "thin" concept of constitution that is focused on its procedure characteristics, Alec Stone Sweet define it "as a body of meta-norms, those higher-order legal rules and principles that specify how other lower-order legal norms are to be produced, applied, enforced, and interpreted. Meta-norms constitute political systems in perpetuity. In today's world, written constitutions are the ultimate, formal source of state authority" (STONE SWEET, Alec, 2009. Constitutionalism, Legal Pluralism, and International Regimes, p. 626. Indiana Journal of Global Legal Studies, vol 16). Based on this idea, he comprehended that some international regimes display features that make them constitutional in a significant sense, conforming a global constitutional order as the case of the specific regimes of the EHCR, the European Union (EU), or the WTO.

${ }^{29}$ BODANSKY, supra note 24, at 574 .

30 COTTIER and HERTIG, supra note 15, at 305.
} 
Therefore, it is possible to understand global constitutionalism as a set of comprehensive values, principles, and rules undertaken by the international belief system and its discourses ${ }^{31}$, which intend to establish fragmented legal frameworks related to a given issue area, with respect to the substance of the constitutional heritage within a legitimated process of recognition and acceptance.

Hence, its main tasks are related to the construction of micro-constitutionalized systems that identify points of overlapping jurisdiction among different scales of governance and actors, to organize specific regimes and adjust them to certain collective demands of the globalized world ${ }^{32}$.

Considering certain doses of idealism that surround the possibility of compensation for the constitutional discharge on the national plane ${ }^{33}$, the polycentric approach and its focus on fragmentation mitigates this problem, presenting itself as an appropriate analytic tool that aims to promote a systematic convergence of policies, emphasizing collective actions, and stimulating the global constitutionalism's narrative, through a focused bottom-up process that has the flexibility of structural conditions for experimentation and learning adaptation ${ }^{34}$.

The constitutional polycentricity method of identifying distinct public collective goods within each social system, and also the functions established outside the Nation-states' frontiers, help to develop sectorial constitutions sustained by a set of comprehensive rules and principles provided by international treaties that recognize the existence of the fragmentation of the global society and the core values and goals of constitutionalism.

\footnotetext{
${ }^{31}$ D'ASPREMONT, Jean (2017). International Law as a Belief System. Cambridge University Press.

${ }^{32}$ As the core values of constitutionalism have to obey a social agenda required by the distinct driven forces presented at the fragmented and globalized international order, it is possible to argue that the current global social agenda composes a micro-global-constitutional system developed from the overarching position of the sustainable development goals, which comprehend a programmatic set of principles, oriented to ensure the rights of present and future generations of world society that include overlaps, for instance, with the micro-globalclimate-constitutionalism.

33 VAN AAKEN, supra note 26, at. 489.

${ }^{34}$ FISCHER-LESCANO, Andreas and TEUBNER, Gunther (2004). Regime-Collisions: The Vain Search for Legal Unity in the Fragmentation of Global Law, p. 1000. Michigan Journal of International Law, vol. 25, pp. 999-1046.
} 


\section{POLYCENTRIC APPROACH AND CLIMATE CHANGE.}

The polycentric approach based on Elinor Ostrom's Theory comprises a viable alternative and pluralistic method of governance that focuses on the action of multiple lower levels. It is an analytical tool to determine global change, operating via independent and overlapping jurisdictions, through experimentation, learning, trust-building, and sensitivity. In this setting, the actions of distinct actors spread out at multiple governance units, enhance their innovative potential within their cooperative actions that are oriented toward the achievement of common public goods.

In an emblematic article entitled "The Organization of Government in Metropolitan Areas: A Theoretical Inquiry' (1961), Vincent Ostrom, Charles Tiebout, and Robert Warren introduce the term 'polycentricity' and explain it as a system "of many autonomous units formally independent of one another, choosing to act in ways that take account of others, through the process of cooperation, competition, and conflict resolution" ${ }^{35}$.

The polycentric system is thus defined as the management of social activities within multiple interrelated units, which should however, be initiated from individual centres when organizing its own actions and relationships with the other units, working to achieve common goals. Vincent Ostrom and his colleagues indicated in that article, the example of the US metropolitan areas, which under definite conditions can construct improved methods of community management than the earlier prevailing standard form of a centralized structure $^{36}$.

Therefore, polycentricity encourages beneficial interactions among several governance units, which include the coordination of their own actions with a reciprocal and cooperative mindset, and which desire to accomplish reciprocal work. The logic involved in this system is completely divergent from the concept of a central authority where potential differences need to be resolved between the various actors and is governed by the rule of law and a series of

35 OSTROM, Vicent, TIEBOUT, Charles M. and WARREN, Robert (1961). The Organization of Government in Metropolitan Areas: A Theoretical Inquiry. American Political Science Review 55 (4), 831-842.

${ }^{36}$ DORSCH, Marcel J. and FLATCHSLAND, Christian (2017). A Polycentric Approach to Global Climate Governance, p. 48. Global Environmental Politics, Vol. 17, Number 2, 45-64. 
overarching regulations. According to Vincent Ostrom's essay (1990), the polycentric order is "one where many elements are capable of making mutual adjustments for ordering their relationships with one another within a general system of rules, where each element acts with independence of the other elements"37.

From a logical perspective, the activity of the local communities emerges as the decisive factor that determines the success or failure of the governance method, based on the polycentric approach, as the lower levels offer a wide scope for experimentation, selection, and learning, guaranteeing innovation, adaptation, trustworthiness, and cooperation via a self-governing method. Hence, the lower levels and their information networks and monitoring levels, based on the collective action have to be comprehended as laboratories of experimentation, producing innovative projects that can serve as models for other jurisdictions on the same or different scales.

Benjamin K. Sovacool, in his support of the polycentric approach and its ability to integrate the strengths of the local and global actions, demonstrated that the policy preferences tend to be more compatible within the smaller units than across the broader ones. In fact, they open up more choices for the citizens to implement a set of regulations, and simultaneously, involve the local actors to conform to a common group of goals and eventually enforce them to the global level 38 .

When "global problems" like climate change are the focus, they refer to the cumulative outcome of the actions of individuals, families, small groups, private firms, or even local, regional, and national governments, which require collective actions that will raise the confidence and reciprocity levels of the individuals concerned, to identify answers for their actions, with the willing cooperation of the citizens ${ }^{39}$, through the development of patterns of social behaviour.

${ }^{37}$ OSTROM, Vicent (1999). Polycentricity - Part . In Polycentricity and Local Public Economics. Ed. Michel Mc Ginis, 52-74. Ann Arbor: University of Michigan Press.

38 SOVACOOL, Benjamin K. (2011). An International Comparison of Four Polycentric Approaches to Climate and Energy Governance, p. 3842/3843. Energy Policy, 39, 3832-3844.

39 OSTROM, Elinor (2010). Polycentric Systems for Coping with Collective Action and Global Environmental Change), p. 550. Global Environmental Change 20, 550-557. 
The benefits and advantages of utilizing the local knowledge and learning from others, is to ultimately construct a sustainable and resilient framework, to ensure the levels of trust and reciprocity of individuals who are affected by unsuccessful negotiations on a global scale and to provide a strong agreement that solves the emergent common problems of the humanity.

Global problems involve an important factor, namely time which is the one variable that is not easily negotiable at the international level, which can frustrate the chances of identifying a fitting solution in time to avert serious backlashes to society. Furthermore, global negotiations require support from several types of efforts at the national, regional, and local levels, for effective functioning. In this context, Ostrom draws attention to the question - even as several outcomes of climate change are global, what actually causes them to take place on a much lower level? - To explain this she introduced the catchy phrase, "Think Globally, Act Locally"40.

Inevitably, much criticism has been levied against the polycentric approach, specifically in terms of the likelihood of the fragmentation in the system and the absence of coordination among the different levels of governance, precipitating potential problems among them. From this perspective, it must be explained that, at this point, the polycentric approach regards the Nation-states as the central authority and the pivotal factor that plays a supportive role by arbitrating and investing in decisive actions and dividing its powers within the different levels of governance available in the climate system.

At any rate, the polycentric approach directs its activities toward a merging of plans embraced by an overarching set of regulations, so as to encourage the coordination of the entire system, increasing to its utmost the potential of several institutions involved in managing global problems, such as, climate change. To a lesser degree, the polycentric mode fosters research and laboratory experimentation, resulting in innovative projects that become models for other jurisdictions on the same or different levels.

Of course, the existence of overarching rules related to the polycentric approach can be derived from a specialized international regime that influences

40 OSTROM, Elinor (2010). A Multi-Scale Approach to Coping with Climate Change and Other Collective Action Problems, p. 28. Solutions 1 (2): 27-36. 
multi-scale governance units and their actions as multipliers of pledges addressed to cope with global problems. Moreover, in a globalized world, where most of the original institutional and regulatory functions of the Nation-states are taken outside their borders, the efforts to construct a narrative based on the idea of global constitutionalism within a polycentric approach has to be centred on the capacity to promote a convergence of policies orientated by the constitutional heritage and the current global social agenda, in order to contribute substantive elements to the resulting systems and escape from "the dictatorship of international financial markets".

To summarize, polycentric systems are characterized by multiple centres of decision-making authority with overlapping jurisdictions that do not stand in hierarchical relationship; instead they compete, and at the same time, cooperate with each other. Their interactions are developed through a process of mutual adjustment with spontaneous collaboration and learning from one another, generating a regularized pattern of an overarching social order ${ }^{41}$.

The Nation-state, under the guidance of the polycentric governance, plays a pivotal part in ensuring that great steps are taken in handling global changes, through intervention and investment in decisive actions that aims to achieve the objectives of increased common public goods ${ }^{42}$.

In this sense, the relationship between Nation-states and polycentricity that addressed global problems is bound by a scheme of comprehensive values, principles, and rules, which express the building-process of climate constitutionalism, which can foster innovation and spread effects positively through the whole global governance system, as successful experiments as well as failures, both play roles in this process, as both can encourage innovation and positively impart support to the entire global climate governance system, with the process of acquiring knowledge and learning.

\section{Fragmentation: Polycentric Approach to Coping with Climate Change}

41 JORDAN, Andrew, HUITEMA, Dave, SCHOENEFELD, Jonas, VAN ASSELT, Harro and FORSTER, Johanna (2018). Governing Climate Change Polycentrically: Setting the Scene, p. 11. In Governing Climate Change: Polycentricity in Action? Cambridge University Press.

42 SOVACOOL, supra note 35 , at 3843. 
The fragmentation can be understood, according to Biermann et al., as a quality of the global governance architecture, characterizing a "patchwork of international institutions that are different in their character (organizations, regimes, and implicit norms), their constituencies (public and private), their spatial scope (from bilateral to global), and their subject matter (from specific policy fields to universal concerns)"43.

In what concerns the international law, fragmentation has to be embraced as it represents an irreversible process and is comprehended from its positive effects as it comprises, according to the report of the International Law Commission, 'the emergence of new 'branches' of the law, novel types of treaties or clusters of treaties" that express a feature of the social complexity of a globalizing world ${ }^{44}$. Certainly, there are conflicts between specialized regimes, but as fragmentation of the international law is a reality, it is important to develop new perspectives of analysis based on methods and techniques for dealing with such collisions ${ }^{45}$ as in the case of the polycentric approach ${ }^{46}$.

\footnotetext{
${ }^{43}$ BIERMANN, F, PATTBERG, P, VAN ASSELT, H, ZELLI, F. (2009) The Fragmentation of Global Governance Architectures: a framework for analysis, p. 16. Global Environmental Politics, 9: 14-40.

44 INTERNATIONAL LAW COMMISSION, ILC (2006) Fragmentation of International Law: Difficulties Arising from the Diversification and Expansion of International Law, p. 222. Report of the Study Group Of the International Law Commission. A/CN. 4/L. 682. Geneva: ILC.

45 ILC, supra note 44, at 493. Commenting the ILC's Report, Harro Van Asselt and colleagues explained: "the ILC has clearly acknowledge that norms of different regimes can collide and that there is a need to conceive of legal and political techniques to address such collisions. Starting from our preoccupation with the climate regime and its position in the wider system of international law, we argue that its many different interactions also provide an ideal testing ground for the considerations of possible methods to address relations between special regimes" (ASSELT, Harro Van, SINDICO, Francesco and MEHLING, Michael, 2008, Global Climate Change and the Fragmentation of International Law, p. 440. Law \& Policy, vol. 30, n. 04, pp. 423-449).

${ }^{46}$ Anne Peters highlighted the relationship between global constitutionalism and fragmentation, considering the use of appropriate methods for the better comprehension of this interaction: "The lens of global constitutionalism, if conceived as a genuinely pluralist framework, allows us to accept and re-assess fragmentation as a positive condition which manifests and facilitates the realization of the constitutional values of critiques and contestation" (PETERS, Anne, 2016. Fragmentation and Globalization, p. 17. In ORFORD, Anne and HOFFMANN, Florian. The Oxford Handbook of the Theory of International Law). If the fragmentation of the international system is an irreversible process, it is necessary to develop an analytical tool that is adapted to this condition, such as polycentricity, with functioning with the flexibility and dynamism that are required to maximize the potential of higher and lower levels of governance, respecting the core values of the Constitutional heritage, and its current social agenda. Through the polycentric approach and its collective actions, multiple and interrelated units with overlapping jurisdictions achieves common goals, coordinated by a set of overarching rules that represent the microglobal-constitutionalized systems and their values and principles, as well as the building process of creating institutions and other norms.
} 
Normally, even as the jurisdiction inside the fragmented global governance architecture can overlap multiple nodes of authority, none is superior to the other, true to the pattern of the polycentric system ${ }^{47}$. However, it is possible to verify also the existence of hierarchical relationships, in which certain institutions are superior to the other - seen among the vertically related institutions. In any case, it must be clear that the hierarchical and polycentric orders are ideal models, with both of their elements being present in several systems. Therefore, identification of the polycentric elements in one system includes interpretation efforts, which are oriented to the contextualization of its dynamics and the logic supporting the relationship present between its institutions.

Considering the existence of different types of relationships inside the fragmented international system and the demand to capture its essence in an appropriate method of analysis, Fariborz Zelli maintained that the global governance architecture for a given area of issue can be outlined by a single treaty, but usually embraces a larger set of agreements under the same legal umbrella, and the associate policy processes involve a range of different organizations, regimes, and other forms of principles, norms, regulations, and procedures. As an example, the current climate international regime presents a fragmented architecture, as it comprises not only the UN Framework Convention on Climate Change (UNFCCC) as its chief subject matter, but also its Kyoto Protocol and the Paris Agreement, the several decisions that were taken by the annual Conference of Parties (COPs), the correspondent negotiation bodies, and procedures. Moreover, the climate governance architecture overlaps with other international regimes that may largely focus on other issues, but nonetheless touch upon climate change ${ }^{48}$.

The circumstance confirms the need for an approach that aims to comprehend the fragmentation and the potential relationships inside and outside the climate governance structure, to address this problem with effective and immediate solutions that go beyond the abstract discourse and inoperative policies that

47 BODANSKY, Daniel, BRUNNÉE, Jutta and RAJAMANI, Lavanya (2017). International Climate Change Law, p. 260. Oxford University Press.

48 ZELLI, Fariborz (2011). The Fragmentation of the Global Climate Governance Architecture, p. 255. WIREs Climate Change, vol. 02: 255-270. 
dominated the negotiations at the global level. Indeed, it is clearly evident that not even one country was able to successfully minimize its greenhouse gas emissions, and neither has a substantial global agreement been formulated thus far to accomplish this task through a centralized logic of governance. Sadly, the United Nations Framework Convention on Climate Change (UNFCC) and the Kyoto Protocol too have failed, due to the unreliable strategies and absence of coordinated implementation in engaging the different levels of control, as well as the groups and individuals, in the battle against the climate crisis $^{49}$.

Daniel H. Cole expressed his apprehensions regarding the poor advancement made in climate negotiations on a global scale, assessing that after "more than 20 years of UN climate meetings little mutual trust has developed so far. Indeed, a review of contemporaneous accounts from recent global climate meetings indicates continuing high levels of distrust, represented not only by lack of progress on mitigation, but also by well-publicized conflicts among parties" 50 .

Currently, the logic securing global climate governance has been modified. From the time of the Paris Agreement, the polycentric approach has been adopted to handle climate change, replacing the monocentric dynamics evident in the Kyoto Protocol. The Paris Agreement acknowledges the general presence of domestic policies that drive climate action and permit countries to set up their own goals for minimizing greenhouse gas emissions, allowing the development of new analytical tools that can contribute to the implementation of its objectives by boosting coordinated initiatives with a bottom-up process, supported by the global constitutionalism's narrative, with the participation of multiple levels of governance.

Robert Falkner emphasized the failed efforts to push for a global deal on mandatory reductions in emissions, suggesting "the new regulatory approach

\footnotetext{
49 In light of these facts, it is feasible to pose the queries related to the ways in which multiple levels of governance are tackling global challenges. It must be checked to see if the connections among international, transnational, national and sub-national initiatives are offering the opportunity to partake in establishing the decision-making process of policies, involving both citizens and institutions in a cooperative atmosphere of confidence and reciprocity, within a polycentric framework, in order to restrain the climate crisis and control global warming.

50 COLE, Daniel H. (2015). Advantages of a Polycentric Approach to Climate Change Policy, p. 117. Nature Climate Change, vol. 05.
} 
adopted by the Paris Agreement managed to transform the international negotiations from a distributional conflict over legally binding targets into a bottom-up process of voluntary mitigation pledges. By allowing countries to determine their mitigation efforts independently, it removed a key barrier that held back the post-Kyoto negotiations" $"$.

The logic undergirding the Paris Agreement proposed for global climate governance reveals the acceptance of the polycentric approach. Its bottom-up process of voluntary mitigation initiatives performed through Nationally Determinate Contributions (NDCs), builds the confidence levels of the countries, as they are offered the chance to determine their own targets, construct coordinate linkages among the various levels of governance supplied by the global climate system, and are able to work toward a common objective, which is to control the current climate crisis.

Certainly, the failed monocentric-based approach of the Kyoto's model of governing, focused on legally binding quantified emission goals, demonstrates the need to adopt a polycentric method in which national ambitions are formulated, reported, and updated over time, through a series of procedural obligations, entailing a revision of the previous consolidated assumptions in the field of climate governance. This should be done to foster initiatives from multiple governing units, as an opportunity for the development of learning and knowledge processes with regard to what works best in different domains.

In this context, Nation-states recovered their pivotal role in the international order, at least in a given issue area, presenting themselves as key institutions for the implementation of mitigation and adaptation actions through the NDCs. As "supportive actors" that ensure climate actions and sustainable development, the Nation-states can influence patterns of consumption and production, encouraging investment in low-carbon technologies and other decisive actions, which highlight the relevant part they play among the vast number and types of actors in the global climate governance arena ${ }^{52}$.

${ }^{51}$ FALKNER, Robert (2016). The Paris Agreement and the New Logic of International Climate Politics, p. 1124. International Affairs, 92, 1107-112.

52 SETZER, Joana and NACHMANY, Michal (2018). National Governance: The State's Role in Steering Polycentric Action, p. 48/49. In JORDAN, Andrew, HUITEMA, Dave, SCHOENEFELD, 
The Nation-states' role in polycentric climate governance can be achieved through intervention, by the establishment of regulatory frameworks, in an attempt to define patterns of social behaviour addressed to cope with climate change, with the participation of the legislative, executive, and judiciary branches of government, and in mobilization by sharing their power with subnational units of the state and non-governmental actors, so as to stimulate them to collaborate in the implementation of policies expressed in the NDCs and to move toward a low-carbon economy.

The polycentric approach of handling climate change enhances the role of the distinct institutions from the international to the lower scales, justifying their active involvement in producing, minimizing, and adapting strategies for the different levels of governance.

For instance, increasing acknowledgment of the crucial role of the national initiatives in dealing with climate issues, especially post the Paris Agreement, has become a reality, and constitutes a part of the present dynamics and logic that underlies the international climate system, and attempts to create a balance between global targets and domestic expectations, for action.

At this point, based on the polycentric approach, the global climate constitutionalism, as an overarching set of shared values, principles, and rules, opens up a way for the self-organized units to effectively coordinate at the societal level, thus averting contradicting actions and low effectiveness and boosting the climate pledges, by helping to converge the efforts of multiple actors involved in handling this issue ${ }^{53}$.

Therefore, the building-process of the micro-global-climate-constitutionalism's narratives, as a set of comprehensive constitutive and regulatory rules, aims to establish principles, values, structures, and procedures related to this specialized regime in order to provide a legal framework to concertize distinct actions that can ensure the quality of coordination and enhance the potential of the fragmented levels of climate governance, settling possible disputes and addressing the efforts toward common strategies.

Jonas, VAN ASSELT, Harro and FORSTER, Johanna (eds) Governing Climate Change: Polycentricity in Action? Cambridge University Press.

53 COLE, Daniel H. (2011) From Global to Polycentric Climate Governance, p. 412. Climate Law, 2, pp. 395-413. 


\section{GLOBAL CLIMATE CONSTITUTIONALISM?}

As an ideal model of governance, the polycentric systems also involve the topdown institutions, which is vital to its formation and maintenance. This facilitates multiple participants to coordinate their activities, resolve disputes between the lower level units, and mutually exchange data regarding their successful strategies, and perhaps even transfers, from one local setting to another ${ }^{54}$.

When constitutionalism deals with the idea of fragmentation, John Trachtman stated, that it "can be seen as a way of introducing hierarchy and order - or at least a set of coordinating mechanisms - into a chaotic system otherwise marked by proliferating institutions and norms" 55 . In this sense, polycentricity can use constitutionalism and its narrative to acquire the necessary coordination among the multiple governance units under its developed system. At the same time, constitutionalism has to adjust itself within the polycentricy, to find ways to reach the fragmented social context imposed by globalization, describing a constitutionalized system that effectively acts in the multiplication of institutional pledges to achieve common goals, in the present case: Coping with climate change.

Thus, the overarching set of rules creates conditions that promote selforganization among the distinct scales of governance and at the same time assures coordination of the entire system of initiatives and guarantees their execution by authorizing any departure from compliance. These rules also supply a lot of information, which facilitates settling disputes and fostering negotiations among the governing units at the higher and lower levels ${ }^{56}$.

Bearing in mind the characteristics of the polycentric approach and its purpose to maximize the innovative potential of a fragmented governance system, the global constitutionalism's narrative can be comprehended as "micro-global-

54 BAUWENS, Thomas (2017). Polycentric Governance Approaches for a Low-Carbon Transition: The Roles of Community-Based Energy Initiatives in Enhancing the Resilience of Future Energy Systems, p. 126. In LABANCA, N. (ed), Complex Systems and Social Practices in Energy Transitions: Framing Energy Sustainability in the Time of Renewables, pp. 119-145, London: Springer.

55 TRACHTMAN, Joel (2014). The Future of International Law: Global Government (n. 42), p. 251/252. Cambridge University Press.

56 SOVACOOL, supra note 35 , at $3842 / 43$. 
constitutions" related to a given issue area, such as, climate change. Hence, these "micro-global-constitutions" recognize the existence of constitutive and regulatory elements stipulated by different kinds of documents that provide the core structure of the system and their own dynamics, highlighting their internal and external overlapping jurisdictions, so as to unite the actions and establish patterns of social behaviour.

In other words, the micro-global-constitutions are part of a broader global constitutionalism mindset that inspire their building-process and aim to provide them an average of enforcement through several polycentric actions in multiple scales of governance, escaping from the soft law's discourse that dominates the international order.

Therefore, the polycentric approach recognizes the fragmentation of the international order and uses it to construct several governance systems related to certain given issue areas, structured by constitutive and regulatory elements that set the features of the overarching rules, and work with an overlapping jurisdiction with each other.

Definitely, there is a challenge in the harmonization of overlapping jurisdictions to construct a narrative discourse linked to the concept of "micro-globalconstitutions," as they are related to identification of the core norms of different international institutions, which could generate potential tensions with each other - as in the case of the international trade and climate regime ${ }^{57}$.

In any case, the overlapping jurisdictions that maximize the potential of multiple institutions to handle climate change, is particularly seen at the lower levels, where their role is more that of a laboratory with experimentations, to produce innovative outcomes that can become models for other jurisdictions to implement, at the same or different levels. This storehouse for potentially transformative concepts at the lower levels is linked to the higher levels of national and international climate processes, particularly, within the bounds of the overarching scheme of rules and its constitutive instruments.

57 ZELLI, F. and VAN ASSELT, H., 2010, The overlap between the UN climate regime and the World Trade Organization: lessons for post-2012 climate governance. In ed. BIERMANN, F., PATTBERG, P. and ZELLI, F. Global Climate Governance beyond 2012: Architecture, Agency and Adaptation. Cambridge: Cambridge University Press, 79-96. 
Daniel Bodansky explained that some constitutive instruments represent the "tip of the normative iceberg within the regimes they establish", providing flexible and dynamic governance arrangements to create norms in a given issue area. In this order of ideas, it is possible to distinguish between constitutive and nonconstitutive elements, allowing a better understanding of the structure and the development of an international environmental regime. On the one hand, the constitutive elements stipulated by the text of the treaty itself or a set of agreements provide the core structure of an international environmental system, establishing its basic institution and decision-making procedures, such as, a Constitution, where the constitutive elements are difficult to amend. On the other hand, the regulatory elements are established in different documents such as protocols, annexes, or schedules, which are easier to amend, or are adopted as decisions of the parties ${ }^{58}$.

In the specific case of the climate governance, the micro-global-climateconstitutionalism could be considered to be part of the international environmental regime, which is composed of a series of micro-globalconstitutions according to the presence of constitutive and regulatory elements that reflect the "constitutionalism's mindset" related to a given environmental area, which overlap in different ways other international regimes, such as, the global animal law, the global energy law, the global trade law, and the like.

At this point, the differences among the concepts of constitutionalism, constitution, and constitutionalization make up an essential part of the discussion again. Indeed, the micro-global-climate-constitutionalism represents a set of comprehensive values, principles, and overarching rules linked to the "constitutionalism mindsef" that sustains the whole global climate system. By its side, the micro-global-climate constitution comprises a constitutive text that operates as the basis of the system, reflecting the values of the micro-globalconstitutionalism related to the climate issue area as well as the procedures to create institutions, and other norms to compose the dynamics of governing the respective system.

Finally, the global-climate-constitutionalization can be comprehended as the process that provides special kinds of norms with the label of "constitutional" in

${ }^{58}$ BODANSKY, supra note 23, at 575. 
the micro-global-climate-constitutionalism that, through the perspective of the polycentric approach, can articulate substantive preferences, distributionary choices, and political objectives to the integration of the system, keeping alive its sense of "common good of humankind ${ }^{59}$ given by the Constitutional heritage. Of course, it is important to settle some boundaries of the building-process of the global climate constitutionalism, which is possible with the application of a methodological tail that represents a first step to define its constitutive element, which is, a treaty text that comprises the micro-global-climate-constitution. This methodological approach is significant to reinforce the coordination of the polycentric units and avoid the potential generation of multiple or infinite fragmented systems, establishing the appropriate limit to develop a "belief system" of the existing micro-global-constitutionalism, which contains the commonly accepted values, principles, and rules.

Following the previous considerations, the United Nations Framework Convention on Climate Change (UNFCCC) can be considered to comprise of the constitutive elements that generate the micro-global-climate-constitution as it presents the substantive and procedural factors that represent its goals and objectives, which attribute to its legitimacy as an overarching rule ${ }^{60}$, establishing the basic structure and the development's pathway of the international climate regime.

Applying the polycentric approach, the UNFCCC can affect significant climate governance as a micro-global-constitution that binds the other regulations, norms, values, and policies related to climate change. It can also ensure that broader goals are achieved, disputes are settled between different institutions and individuals, and potential dominance by any one of the participant players is averted. For instance, the core principles of the UNFCCC expressed an overarching set of rules, such as, the principle of 'common but differentiated responsibilities and respective capabilities' that indicate those accountable for the climate crisis and those who are better capable of dealing with it (in terms

\footnotetext{
59 ILC, supra note 44 , at 480 .

60 OBERTHÜR, Sebastian (2016). Reflections on global climate politics post Paris: Power, Interests and Polycentricity. The International Spectator, 51(4), 80-94.
} 
of, for e.g., financial resources) ${ }^{61}$, or the principle of the 'common concern of humankind" that represents the importance of "prevent dangerous anthropogenic interference with the climate system" for development and human welfare, and the inevitable cooperative approach involving the whole world to confront this crisis ${ }^{62}$.

The particular dynamics of the micro-global-climate-constitutionalism provided by the polycentric approach constantly seeks effectiveness by its own constitutionalization process, so as to recover the trust and promote mutual adjustments among distinct actors and stakeholders. This process is confirmed or amended through the decision-making taken by the Conference of the Parties (COPs), and acquires expressive, operational, and legal significance in the climate regime, enriching and expanding the normative core of the regime by fleshing out provisions, reviewing the adequacy of existing obligations, and launching negotiations to adopt further agreements ${ }^{63}$.

It means, the COPs' decisions symbolize a constant work-in-progress, to outline the institutional architecture of the international climate regime and to achieve the common purposes of the planetary fight against climate change, innovating and promoting laboratories for experimentation in order to foster convergence of interests and actions among multiple actors (governmental and nongovernmental) and stakeholders.

Certainly, these dynamics are characterized by turning points, in correspondence with schemes derived from political negotiations involving the driven forces that act in the global climate governance and dictate the essence and dynamics of its constitutionalization process. At present, the turning points could be represented by the distinct logic of the Kyoto's model of governing, focused on a monocentric and centralized approach ${ }^{64}$, and the Paris

\footnotetext{
61 RAJAMANI, Lavanya (2013). Differentiation in the Emerging Climate Regime. Theoretical Inquires in Law, 14 (1), 151-171.

62 SOLTAU, Frederiech (2016) Common Concern of Humankind, p. 08. In CARLARNE, Cinnamon, GRAY, Kevin R. and TARASOFSKY, Richard. Oxford Handbook of International Climate Change Law.

${ }^{63}$ BODANSKY, BRUNNÉE and RAJAMANI, supra note 41, at 19.

64 Historically, the constitutive and multilateral framework provided by the UNFCCC was considered the place where "the grand bargain should emerge that would enable and unlock climate action at the other governance levels" (OBERTHÜR, Sebastian, 2016, Where to go from Paris? The European Union in Climate Geopolitics. Journal of Global Affairs, vol. 02, Issue 2, pp. 119-130). In this sense, the Kyoto Protocol of 1997 and its centralized model of governing
} 
Agreement, attempt for a decentralized framing and the polycentric features of the system in which a variety of governance levels (local, regional, national, supranational, international), public and private actors, and fora are recognized as driving forces of climate action in their own right ${ }^{65}$.

This perspective of analysis can be visualized on the original broader goal of the UNFCCC that aimed to 'stabilize greenhouse gas emissions at a level that would avoid dangerous anthropogenic interference with the climate system' (Article 2), which was too general, demanding a more specific guidance to be issued. Nowadays, the Paris Agreement promotes the goal for the temperature to stay well below $2^{\circ} \mathrm{C}$ detailing the objective of the UNFCCC, but also adding the $1.5^{\circ} \mathrm{C}$ goal as well, so as to achieve net zero carbon emissions during the second half of this century, offering further specificity with regard to the 'rules of the game'66.

On the one hand, the specification provided by the Paris Agreement comprises the peculiar dynamics of the constitutionalization process in the international climate system and the composition of its set of overarching rules, as it defines the future global commitments in terms of mitigation and adaptation. On the other hand, confirming the categorization of the UNFCCC as an overarching ruling body and the extension of this constitutive element, in keeping with the logic undergirding the Paris Agreement, amplifies the advantages of the polycentric approach.

Furthermore, it is clear that the Paris Agreement improved the logic of the system from a monocentric to a polycentric approach, leaving the implementation of mitigation action largely to the states, but did not change the constitutive aspect of the UNFCCC, reinforcing its role as micro-global-climate-

was unsuccessful in its goal of promoting the required international broadening and deepening of climate action, marking the regime with impasses during much of 2000 , which culminated in the disappointing Copenhagen Summit in 2009.

65 OBERTHÜR, supra nota 51 , at 89.

66 VAN ASSELT, Harro and ZELLI, Fariborz (2018). International Governance Polycentric Governing by and beyond the UNFCCC, p. 41. In JORDAN, Andrew, HUITEMA, Dave, SCHOENEFELD, Jonas, VAN ASSELT, Harro and FORSTER, Johanna (eds) Governing Climate Change: Polycentricity in Action? Cambridge University Press. 
constitution that provides direction (and orchestrating) to the dynamically evolving governance and legitimating climate protection activities ${ }^{67}$.

As part of the set of overarching rules that compose the micro-global-climateconstitutionalism, the Paris Agreement reforms and provides guidance for the evolution of the framework of the international climate regime, attributing normative validity and acceptance to it, with the engagement of governments and societal actors increasing its polycentric institutional architecture, as well as enhancing the potential for its implementation and related behavioral adaptations.

The importance of the building-process of the global climate constitutionalism can be verified not only by the characterization of the international law in constitutional terms, so as to relate it to the constitutive function of many treaties, but particularly by the claims about the constitutional status of the set of overarching rules that act in the international climate regime, which usually serve as a shorthand for a stronger set of relevant claims ${ }^{68}$, such as the relationship between climate change and human rights ${ }^{69}$, revealing the descriptive and normative applications that can be provided by the polycentric approach and the global constitutionalism's narrative.

In this sense, the concept of micro-global-climate-constitution can be comprehended not only as a foundation for the convergence of policies, but also as a sustainable legal framework to be applied normatively, to support the climate litigation ${ }^{70}$ and to protect vulnerable groups and individuals affected by

\footnotetext{
67 OBERTHÜR, supra nota 51 , at 91.

68 BODANSKY, supra note 23 , at 575 .

69 John Knox explained that the relationship between human rights and climate change is still in its infancy as the human rights do not address climate change explicitly, and climate change treaties do not refer to human rights. Therefore, considering the existence of superficial links between these regimes, the problem is whether States breach their legal obligations by failing to take steps to prevent or respond to the effects of climate change on human rights (Human Rights Principles and Climate Change. In CARLARNE, Cinnamon, GRAY, Kevin R. and TARASOFSKY, Richard. Oxford Handbook of International Climate Change Law). Applying the concept of micro-global-climate-constitutionalism and its system, it is possible to verify whether the States have accomplished their international commitments concerning climate change in order to guarantee in their own territory and jurisdiction the full enjoyment of human rights, protection of people through the adoption of the adaptation and mitigation measures.

70 The insufficiency of scientific evidence that prove the existence of direct links between the causes that produce the migration and the climate change and its transboundary effects is considered an obstacle to finding solutions within the international legal community in order to recognize and address the situation of individuals and groups forced to move from the original habitat induced by environmental degradation. One of the main questions concerning climate
} 
global warming, as in the case of the climate migrants, who are still expecting their categorization to be protected by the international law ${ }^{71}$.

The implementation of the polycentric approach as a mechanism to construct the micro-global-climate-constitutionalism's narrative is part of a progressive process that is not yet completed. It depends on the "orchestration" provided by the micro-global-climate-constitution (UNFCCC) and its ability to sustain the process of constitutionalization of regulatory norms as in the Paris Agreement, which aims to specify structures and division of labour, to ensure core governance functions (creation of consensual knowledge assessments, overall target setting, development of regulation/policies, mobilization of finance and investment, capacity building, etc.) ${ }^{72}$ and to engage the distinct actors (governmental and non-governmental) in the decision-making process and generation of patterns of social behaviour, oriented to cope with climate change.

migration is incorporation of this category of vulnerable persons within the existing framework of the Refugee Convention, as this is an increasing humanitarian crisis need for an urgent response. In this sense, Angela Williams considered that it is necessary to move away from traditional conceptions of refugee discourse to follow the dynamics of the global transformations in order to respond to present-day challenges. Hence, she suggested: "the best way forward lies with harnessing regional cooperation between states and building on existing geopolitical, economic, cultural, and environmental relationships that already exist within many regional frameworks" (WILLIANS, Angela, 2008, Turning the Tide: Recognizing Climate Change Refugees in International Law, p. 524. Law and Policy, 30, pp. 502-529). Once more, the polycentric approach to coping with climate change and its effects appears as an appropriate method to promote a learning and knowledge process that can effectively answer global problems. Moreover, the concept of micro-global-constitutionalism can be used as a legal framework that aims to enhance and multiply the action of multiple levels of governance, overlapping with the other international system in order to protect the rights of the climate migrants through the generation of uniform global standards that support the implementation of policies and justifiability of this humanitarian claim.

71 The climate change litigation consists of a key element in the dynamics of the micro-globalconstitutionalism, as it provides overlapping functions that link the international climate regime with other international and national regimes, such as, the international human rights system or the global energy law or even the own accomplishment of the NDCs through domestic laws, maximizing the potential of the polycentric approach to reach concrete answers to, for instance, protect the rights of people affected by the adverse effects of the environmental degradation, as in the case of the climate migrants or limit GHG emission by compelling government decisionmakers to consider future 'climate change associated risks' when planning their decisions (PRESTON, Brian J., 2011, The influence of Climate Change Litigation on Governments and the Private Sector, p. 02. Climate Law, 485). As a mechanism that attracts public attention and pressures governments to reach political solutions through international commitments and national laws (POSNER, Eric A., 2007, Climate Change and International Human Rights Litigation: A Critical Appraisal, p. 1944. University of Pennsylvania Law Review, 155, pp. 19251945), the climate litigation constitutes an alternative and pluralistic pathway to cope with the climate crisis and its effects, promoting mitigation and adaptation within the polycentric approach, by application of the global constitutionalism's narrative.

72 OBERTHÜR, supra nota 51, at 90. 


\section{CONCLUSION}

With respect to the question related to global constitutionalism, it means discussing a matter of globalization, as the problem involves historical and discursive perspectives that integrate empirical factors to develop a "belief system" sustained by commonly accepted values, principles, and rules that balance the relationship among the international institutions, the Nation-States, and other levels of governance.

In this context, the (re-) interpretation of constitutionalism is directly linked to the current role of the Nation-states and their decreasing power, as also the institutional and functional anachronisms imposed by the "dictatorship of international financial markets," which characterize the globalized world and aim to promote a convergence of policies orientated to the interests of the capital accumulation of the transnational private corporation and denationalization of regulations, as the race-to-the-bottom's theory proclaimed.

To survive in the globalized international arena, the readjustment of the Nationstates' capacity to deal with common public goods, social protection, and the power of the transnational private corporation requires the construction of a constitutional framework, circumscribed by a program of values and principles that reach beyond their boundaries and involve different levels of governance in a cooperative ambience of trust, solidarity, and mutual adjustments.

Thus, the idea of global constitutionalism has to comprise of a careful and comprehensive revision and reading of the constitutional agenda, to stimulate the launch of descriptive and prescriptive elements into the global governance system, as a manner in which to enhance its potential and engage distinct actors and stakeholders, recognizing the existence of a fragmented and globalized world.

Following these considerations, the global constitutionalism must identify the constitutive and regulatory aspects related to a given issue area that, in the present case, are represented by a sort of international environmental agreement, which establishes institutions and specifies the basic values, 
principles, and rules, promoting the descriptive construction of micro-globalconstitutionalized systems.

With regard to the international climate architecture, the UNFCCC is setting up a constitutive document that provides a scheme of substantive and procedural elements, to support and coordinate the multi-layered climate governance system, categorizing this document as a sectorial constitution, or in other words, a micro-global-climate constitution.

The normative core of this regime is complemented by the decision-making taken by the COPs, which promotes evolving of the legal framework of the international climate system in a dynamic process of constitutionalization and innovation, as in the case of some key documents, such as, the Kyoto Protocol and the Paris Agreement and their distinct models of governing, representing turning points in the logic of this regime.

Under the Paris Agreement's logic, the international climate regime is sustained by the polycentric approach in which the Nation-States function as the key authority, intervening and mobilizing other levels of governance and stakeholders, as well as developing a supportive role in handling the climate crisis, as they independently set up their own goals in terms of mitigation efforts performed through NDCs.

In other words, the NDCs define the pivotal participation of Nation-states in the development of international climate governance, recovering their role as a supportive key institution for the future commitments of the Paris Agreement, and at the same time, reinforce the polycentric institutional dynamics of global climate governance.

Therefore, the polycentric approach focuses on a combination strategies that are designed to deal with the aims of the multi-layered climate governance, to maximize its potential so as to build linkage structures that overcome boundaries and develop convergent policies that respect the legal framework provided by the micro-global-climate-constitutionalism orchestrated by the UNFCCC and the Paris Agreement, congregating the efforts for solidarity from all Nation-States toward a common goal: Overcoming a Top Global Threat. 


\section{REFERENCES}

ARMINGEON, K. and MILEWICZ, K. (2006) Compensatory Constitutionalism: A Comparative Perspective. NCCR International Trade. Working Paper n. 13. ASSELT, Harro Van, SINDICO, Francesco and MEHLING, Michael (2008) Global Climate Change and the Fragmentation of International Law. Law \& Policy, vol. 30, n. 04, pp. 423-449

BAUWENS, Thomas (2017). Polycentric Governance Approaches for a LowCarbon Transition: The Roles of Community-Based Energy Initiatives in Enhancing the Resilience of Future Energy Systems. In LABANCA, N. (ed), Complex Systems and Social Practices in Energy Transitions: Framing Energy Sustainability in the Time of Renewables, pp. 119-145, London: Springer.

BIERMANN, F, PATTBERG, P, VAN ASSELT, H, ZELLI, F. (2009) The Fragmentation of Global Governance Architectures: a framework for analysis. Global Environmental Politics, 9: 14-40.

BLOCK, Fred (1996). The Vampire States and Other Stories. New York: New Press.

BODANSKY, Daniel (2009). Is There an International Environmental Constitution? Indiana Journal of Global Legal Studies, vol. 16, pp. 565-584. ., BRUNNÉE, Jutta and RAJAMANI, Lavanya (2017). International Climate Change Law. Oxford University Press.

CABLE, Vicent. (1995) The Diminished Nation-State: A Study in the Loss of Economic Power. Daedalus, vol. 124, n. 02, What Future for the State?, pp. 2353.

CHIMNI, B. S. (2004). International Institutions Today: An Imperial Global State in the Making. European Journal of International Law, 15, pp. 01-37.

COLE, Daniel H. (2011) From Global to Polycentric Climate Governance. Climate Law, 2, pp. 395-413. . (2015). Advantages of a Polycentric Approach to Climate Change Policy, p. 117. Nature Climate Change, vol. 05.

COTTIER, Thomas and HERTIG, Maya (2003). The Prospects of $21^{\text {st }}$ Century Constitutionalism. Max Planck Yearbook of United Nations Law, Volume 7, pp. 261-328.

D'ASPREMONT, Jean (2017). International Law as a Belief System. Cambridge University Press. 
DORSCH, Marcel J. and FLATCHSLAND, Christian (2017). A Polycentric Approach to Global Climate Governance. Global Environmental Politics, Vol. 17, Number 2, pp. 45-64.

DREZNER, Daniel W. (2001) Globalization and Policy Convergence. International Studies Review, vol. 3, n. 1, pp. 53-78.

EVANS, Peter (1997). The Eclipse of the State? Reflections on Stateness in an Era of Globalization. World Politics, vol. 50, n. 01, pp. 62-87.

FISCHER-LESCANO, Andreas and TEUBNER, Gunther (2004). RegimeCollisions: The Vain Search for Legal Unity in the Fragmentation of Global Law. Michigan Journal of International Law, vol. 25, pp. 999-1046.

FALKNER, Robert (2016). The Paris Agreement and the New Logic of International Climate Politics. International Affairs, 92, pp. 1107-112.

GARDBAUM, Stephen (2009). Human Rights and International Constitutionalism. In Ruling the World? Constitutionalism, International Law and Global Government, Jeffrey L. Dunoff, Joel P. Trachtman, Cambridge University Press, 2009.

INTERNATIONAL LAW COMMISSION, ILC (2006) Fragmentation of International Law: Difficulties Arising from the Diversification and Expansion of International Law. Report of the Study Group Of the International Law Commission. A/CN. 4/L. 682. Geneva: ILC.

JORDAN, Andrew, HUITEMA, Dave, SCHOENEFELD, Jonas, VAN ASSELT, Harro and FORSTER, Johanna (2018) Governing Climate Change: Polycentricity in Action? Cambridge University Press.

KNOX, John (2015). Human Rights Principles and Climate Change. In CARLARNE, Cinnamon, GRAY, Kevin R. and TARASOFSKY, Richard. Oxford Handbook of International Climate Change Law.

KOSKENNIEMI, Martti (2007). Constitutionalism as Mindset: Reflections on Katian Themes about International Law and Globalization. Theoretical Inquires in Law 8.1, pp. 09-36.

MÜLLER, Thomas (2014). Global Constitutionalism in Historical Perspective: Towards refined tools for International Constitutional Histories. Global Constitutionalism, 3: 1, pp. 71-101. Cambridge University Press OBERTHÜR, Sebastian (2016). Reflections on global climate politics post Paris: Power, Interests and Polycentricity. The International Spectator, 51(4), 80-94. 
., 2016, Where to go from Paris? The European Union in Climate

Geopolitics. Journal of Global Affairs, vol. 02, Issue 2, pp. 119-130

OSTROM, Elinor (2010). A Multi-Scale Approach to Coping with Climate Change and Other Collective Action Problems, p. 28. Solutions 1 (2): pp. 27-36. . (2010). Polycentric Systems for Coping with Collective Action and Global Environmental Change), p. 550. Global Environmental Change 20, pp. 550-557.

OSTROM, Vicent (1999). Polycentricity - Part . In Polycentricity and Local Public Economics. Ed. Michel Mc Ginis, pp. 52-74. Ann Arbor: University of Michigan Press (1999).

., TIEBOUT, Charles M. and WARREN, Robert (1961). The Organization of Government in Metropolitan Areas: A Theoretical Inquiry. American Political Science Review 55 (4), pp. 831-842.

PETERS, Anne. (2006) Compensatory Constitutionalism: The Function and Potential of Fundamental International Norms and Structures. Leiden Journal of International Law, 19, pp. 579-610.

. and ARMIGEON, K. (2009) Global Constitutionalism from an Interdisciplinary Perspective, p. 389. Indiana Journal of Global Legal Studies, vol. 16, n. 02, Special Issue, pp. 385-395.

. (2007) The Constitutionalization of State Constitutions. In J. Nijman and A. Nollkaemper (Eds.) New Perspectives on the Divide Between National and International Law. Oxford: Oxford University Press, pp. 251-308.

. (2017) Global Constitutionalism: The Social Dimension, p. 37. MPIL Research Paper Series, n. 2017-25

. (2009) The Merits of Global Constitutionalism, p. 405. Indiana Journal of Global Studies: Vol. 16: Issue 2, Article 2, pp. 397-411.

. (2016). Fragmentation and Globalization. In ORFORD, Anne and HOFFMANN, Florian. The Oxford Handbook of the Theory of International Law PRESTON, Brian J. (2011) The influence of Climate Change Litigation on Governments and the Private Sector. Climate Law, 2/4: 485.

POSNER, Eric A. (2007) Climate Change and International Human Rights Litigation: A Critical Appraisal. University of Pennsylvania Law Review, 155, pp. 1925-1945

POLANYI, Karl (1944). The Great Transformation. Boston: Beacon Press. 
RAJAMANI, Lavanya (2013). Differentiation in the Emerging Climate Regime. Theoretical Inquires in Law, 14 (1), pp. 151-171.

RODRIK, Dani (1997). The 'Paradoxes' of the Successful State. European Economic Review, vol. 41, issue 3-5, pp. 411-442.

SETZER, Joana and NACHMANY, Michal (2018). National Governance: The State's Role in Steering Polycentric Action. In JORDAN, Andrew, HUITEMA, Dave, SCHOENEFELD, Jonas, VAN ASSELT, Harro and FORSTER, Johanna (eds) Governing Climate Change: Polycentricity in Action? Cambridge University Press.

SOLTAU, Frederiech (2016) Common Concern of Humankind. In CARLARNE, Cinnamon, GRAY, Kevin R. and TARASOFSKY, Richard. Oxford Handbook of International Climate Change Law.

SOVACOOL, Benjamin K. (2011). An International Comparison of Four Polycentric Approaches to Climate and Energy Governance. Energy Policy, 39, 3832-3844.

STONE SWEET, Alec, 2009. Constitutionalism, Legal Pluralism, and International Regimes. Indiana Journal of Global Legal Studies, vol 16.

TRACHTMAN, Joel (2014). The Future of International Law: Global Government (n. 42), p. 251/252. Cambridge University Press.

VAN AAKEN, Anne (2009). Defragmentation of Public International Law Through Interpretation: A Methodological Proposal. Indiana Journal of Global Legal Studies, vol. 16, pp. 483-512.

VAN ASSELT, Harro and ZELLI, Fariborz (2018). International Governance Polycentric Governing by and beyond the UNFCCC. In JORDAN, Andrew, HUITEMA, Dave, SCHOENEFELD, Jonas, VAN ASSELT, Harro and FORSTER, Johanna (eds) Governing Climate Change: Polycentricity in Action? Cambridge University Press.

WILLIANS, Angela (2008) Turning the Tide: Recognizing Climate Change Refugees in International Law. Law and Policy, 30, pp. 502-529.

ZELLI, Fariborz (2011). The Fragmentation of the Global Climate Governance Architecture. WIREs Climate Change, vol. 02: pp. 255-270.

. and VAN ASSELT, H., 2010, The overlap between the UN climate regime and the World Trade Organization: lessons for post-2012 climate governance. In ed. BIERMANN, F., PATTBERG, P. and ZELLI, F. Global 
Climate Governance beyond 2012: Architecture, Agency and Adaptation. Cambridge: Cambridge University Press, 79-96. 